\title{
Correction to: Screening for Behavioral Health Issues in Primary Care
}

Jessy Joseph, $M D^{1}$

Faisal Kagadkar, MBBS ${ }^{2}$

Cathryn A. Galanter, $M D^{3, *}$

\section{Address}

${ }^{1}$ State University of New York Downstate, 451 Clarkson Avenue, Brooklyn, NY, 11203, USA

${ }^{2}$ Kings County Hospital Center, 451 Clarkson Avenue, Brooklyn, NY, 11203, USA

${ }^{*}, 3$ State University of New York/Kings County Hospital Center Child and Adolescent Psychiatry, 451 Clarkson Avenue, Room A1218, Brooklyn, NY, 11203, USA

Email: cathryn.galanter@downstate.edu

Published online: 18 May 2018

(C) Springer International Publishing AG, part of Springer Nature 2018

The online version of the original article can be found at https://doi.org/10.1007/s40746-018-0118-z

\section{Correction to: Curr Treat Options Peds https://doi.org/10.1007/s40746-018-0118-z}

The original version of this article, unfortunately, contained an error. The table below shows the incorrect and correct columns.

The original article has been corrected. 


\begin{tabular}{|c|c|c|}
\hline $\begin{array}{l}\text { Page No. } \\
\text { Section } \\
\text { Paragraph No. } \\
\text { Line No. }\end{array}$ & Incorrect & Correct \\
\hline $\begin{array}{l}\text { Page } 1 \\
\text { Abstract } \\
\text { Line } 5\end{array}$ & $\begin{array}{l}\text { Bright Futures/the American } \\
\text { Academy of }\end{array}$ & Bright Futures/American Academy of \\
\hline $\begin{array}{l}\text { Page } 1 \\
\text { Abstract } \\
\text { Line } 6\end{array}$ & and the AAP's Task Force & and the AAP Task Force \\
\hline $\begin{array}{l}\text { Page } 2 \\
\text { Introduction } \\
1^{\text {st }} \text { Paragraph } \\
\text { Lines } 4-5\end{array}$ & $\begin{array}{l}\text { Impairment or lack of developmentally } \\
\text { appropriate behavioral and } \\
\text { emotional control }\end{array}$ & $\begin{array}{l}\text { Impairment in behavioral } \\
\text { and emotional control }\end{array}$ \\
\hline $\begin{array}{l}\text { Page } 2 \\
\text { Introduction } \\
1^{\text {st }} \text { Paragraph } \\
\text { Line } 6\end{array}$ & also contributes to the leading & also contribute to the leading \\
\hline $\begin{array}{l}\text { Page } 2 \\
\text { Introduction } \\
2^{\text {nd }} \text { Paragraph } \\
\text { Line } 4\end{array}$ & $\begin{array}{l}\text { In the last decade, The US } \\
\text { Preventive Services }\end{array}$ & The US Preventive Services \\
\hline $\begin{array}{l}\text { Page } 2 \\
\text { Introduction } \\
2^{\text {nd }} \text { Paragraph } \\
\text { Line } 5\end{array}$ & Bright Futures/the & Bright Futures/American \\
\hline $\begin{array}{l}\text { Page } 2 \\
\text { Introduction } \\
2^{\text {nd }} \text { Paragraph } \\
\text { Line } 6\end{array}$ & $(B F / A A P)$, & (hereafter referred to as BF/AAP), \\
\hline $\begin{array}{l}\text { Page } 2 \\
\text { Introduction } \\
\text { Last Paragraph }\end{array}$ & $\begin{array}{l}\text { This paper aims to (1) summarize } \\
\text { recent research findings pertaining } \\
\text { to behavioral health screening, } \\
\text { (2) describe current recommendations } \\
\text { for behavioral health screening, and } \\
\text { (3) describe screening guidelines and } \\
\text { potential screening tools that a primary } \\
\text { care clinician can use in practice. }\end{array}$ & $\begin{array}{l}\text { This paper aims to (1) describe current } \\
\text { recommendations for behavioral health } \\
\text { screening, (2) describe screening } \\
\text { guidelines and potential screening tools } \\
\text { that a primary care clinician can use in } \\
\text { practice, and (3) summarize recent } \\
\text { research findings pertaining to behavioral } \\
\text { health screening. }\end{array}$ \\
\hline $\begin{array}{l}\text { Page } 2 \\
\text { Screening guidelines and } \\
\text { recommendations } \\
1^{\text {st }} \text { Paragraph } \\
\text { Lines } 6-7\end{array}$ & $\begin{array}{l}\text { Identifying Infants and Young Children } \\
\text { with Developmental Disorders }\end{array}$ & $\begin{array}{l}\text { Identifying Infants and Young Children } \\
\text { with Developmental Disorders }\end{array}$ \\
\hline $\begin{array}{l}\text { Page } 2 \\
\text { Screening guidelines and } \\
\text { recommendations } \\
2^{\text {nd }} \text { Paragraph } \\
\text { Line } 8\end{array}$ & checkups and especially in & checkups, especially in \\
\hline $\begin{array}{l}\text { Page } 3 \\
\text { Screening guidelines and } \\
\text { recommendations }\end{array}$ & $\begin{array}{l}\text { substance use. In addition, } \\
\text { they recommended }\end{array}$ & substance use. They also recommended \\
\hline $\begin{array}{l}2^{\text {nd }} \text { Paragraph } \\
\text { Line } 8\end{array}$ & & \\
\hline $\begin{array}{l}\text { Page } 3 \\
\text { Screening guidelines and }\end{array}$ & $\begin{array}{c}\text { AAP (hereafter referred to as } \\
\text { BF/the AAP) has made }\end{array}$ & with AAP has made \\
\hline
\end{tabular}


Page No.

Incorrect

Correct

\section{Section}

\section{Paragraph No.}

\section{Line No.}

recommendations

$3^{\text {rd }}$ Paragraph

Lines 1 - 2

Page 3

Screening guidelines and

The US Preventative Services Task Force (USPSTF) published several

recommendations

$4^{\text {th }}$ Paragraph

Line 1

Page 3

Screening guidelines and recommendations

$5^{\text {th }}$ Paragraph

Lines 2 - 3

Page 3

Screening guidelines and recommendations

$6^{\text {th }}$ Paragraph

Line 3

Page 3

Infancy and early childhood (ages $0-5$ years)

$1^{\text {st }}$ Paragraph

Line 6

Table 1 Caption

Page 5

Psychosocial/behavioral

assessments

Line 1

Page 5

Psychosocial/behavioral assessments

Line 6

Page 5

Disorder-specific screening

Page 5

Autism spectrum disorder

Page 5

Autism spectrum disorder

$1^{\text {st }}$ Paragraph

Line 1

Page 6

Maternal depression

Lines 2 - 3

Page 6

ADHD

Line 6
(AAP'S TFOMH, USPSTF, and $B F /$ the AAP)

general MH disorders

rates of behavioral health

conditions

Behavioral health screening guidelines from Bright Futures/the American Academy of Pediatrics, the USPSTF, and the American Academy of Pediatrics Task Force on Mental Health

psychosocial/behavior assessments

school-age children.

“Disorder-specific screening" section 2

Heading "Autism spectrum disorder"

Bright Futures/the AAP guidelines

both Bright Futures/the AAP and

The Corner's
The USPSTF published several

(AAP TFOMH, USPSTF, and BF/AAP)

general mental health disorders

rates of $\mathrm{BH}$ conditions

\author{
Behavioral Health Screening Guidelines \\ from Bright Futures/American Academy \\ of Pediatrics, the USPSTF, and the \\ American Academy of Pediatrics Task \\ Force on Mental Health
}

psychosocial/behavioral assessments

middle childhood section.
“Disorder-specific screening" should be section 3

Should be "Autism spectrum disorders"

BF/AAP guidelines

both BF/AAP and

The Corners 


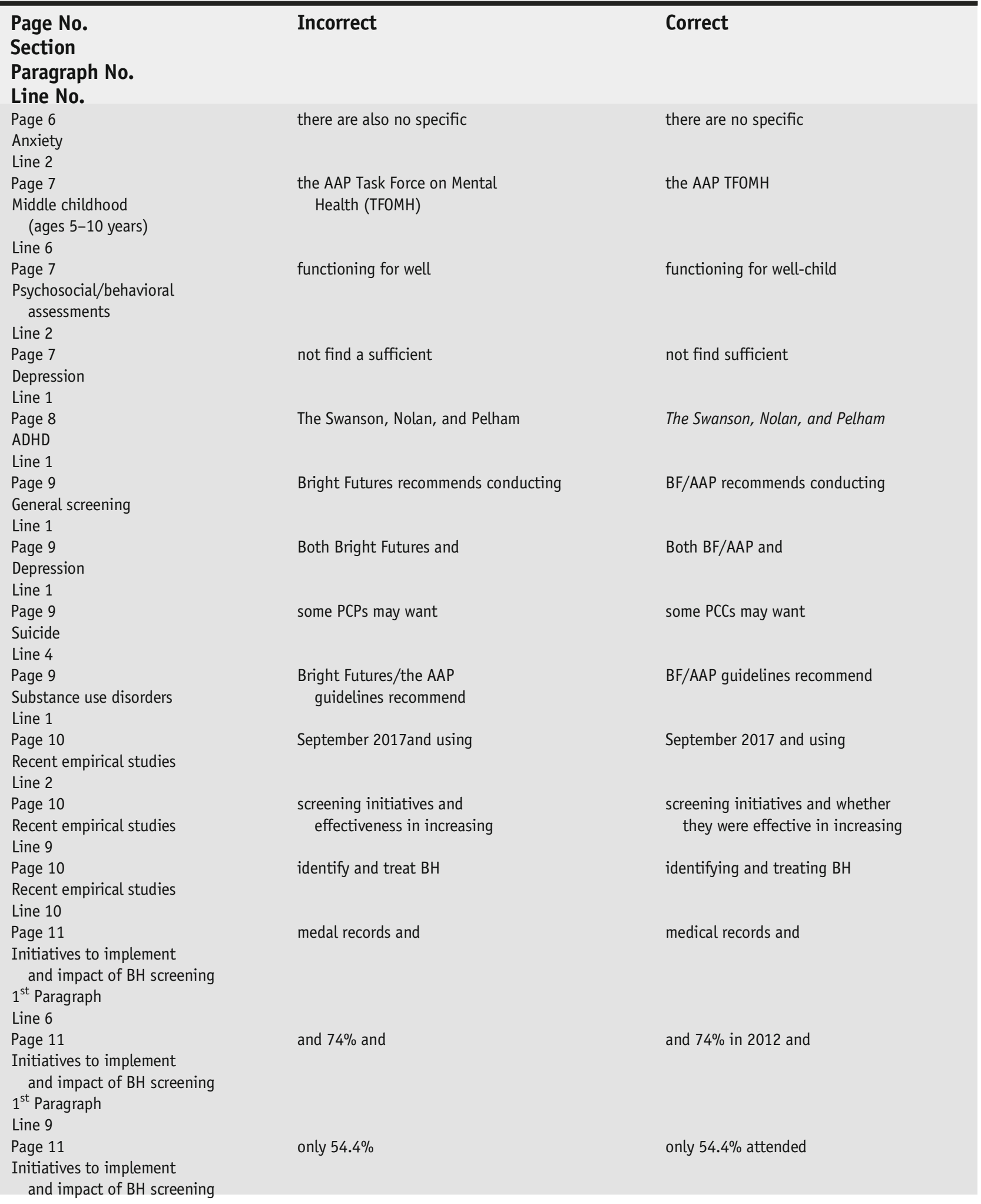




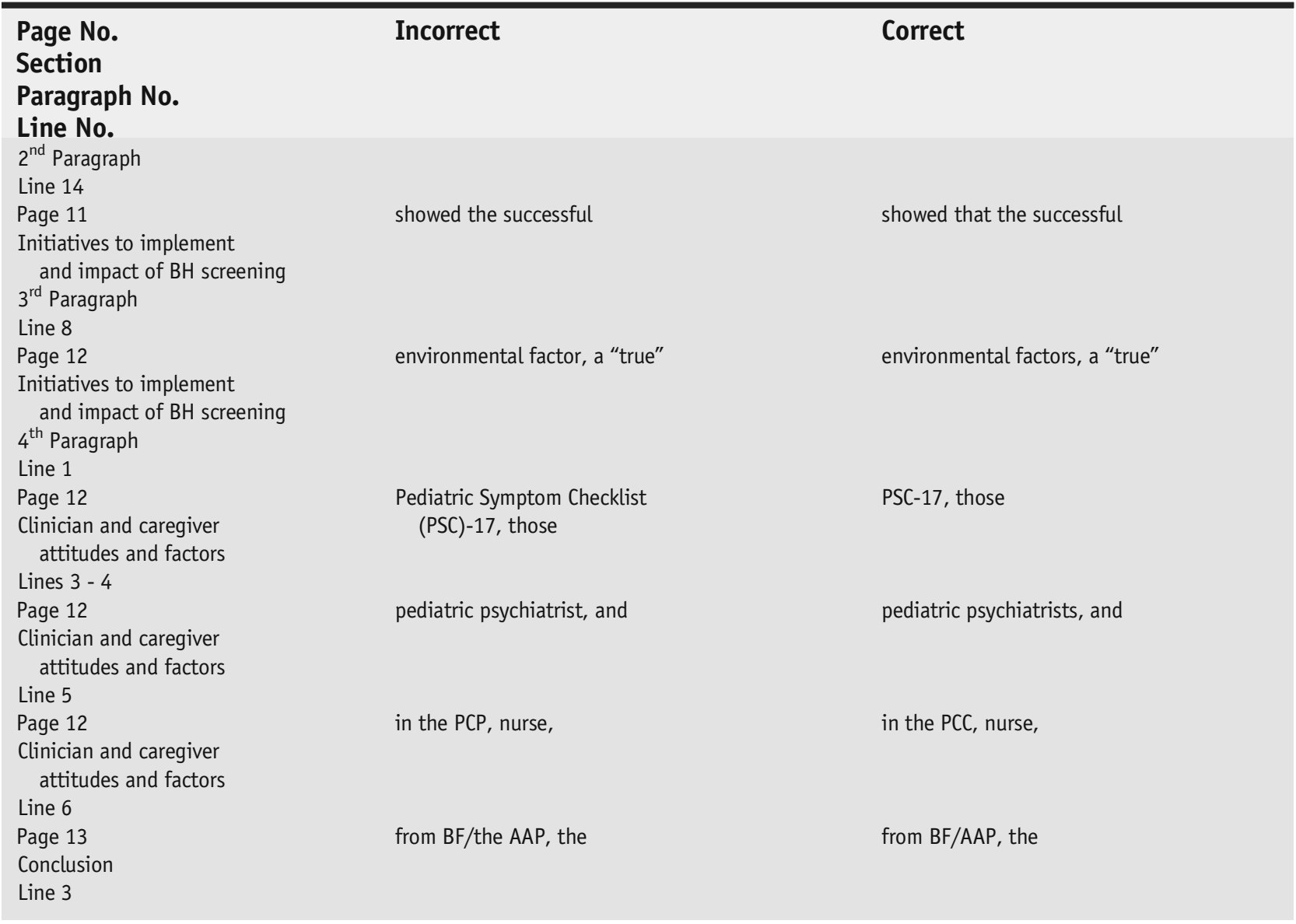

